\title{
ENTWICKLUNGSCHANCEN DER GRENZNAHEN GEBIETE VON UNGARN
}

\author{
Istvan Berenyi*
}

Izvleček

RAZVOJNE MOŽNOSTI V OBMEJNIH OBMOČJIH MADŽARSKE

UDK 911.3(439-04)

Članek prinaša razmišljanja o razvojnih procesih vobmejnih območjih ob zahodnih madžarskih mejah v procesu političnih in gospodarskih sprememb ter evropskih integracijskih procesov.

Ključne besede: Meja, mejna območja, regionalni razvoj, regionalno planiranje, Madžarska

The article presents major characteristics of the development process in border regions along western frontiers of Hungary. The focus is on political and economic changes which swept across Europe in the late 1980.s and 1990.

Key words: Border, border regions, regional development, regional planning, Hungary

\section{DIE PROBLEMSTELLUNG}

Der Begriff der "Grenze" (Grenze, granizze, grani) wurde im deutschen Sprachgebiet von Luther eingeführt und dieser entspricht dem althochdeutschen Begriff "die Mark". Die "Grenzmark" bezeichnete ursprünglich ein siedlungsarmes Gebiet oder sogar einen Raum ohne Siedlungen, der zwei Siedlungen oder zwei Gebiete voneinander trennt. Diese grenznahen Gebiete verschmählerten sich allmählich und wurden Linien (Grenzlinien) und sie bezeichen heute nachn die Grenzen der Verwaltungsgebiete (politisch), die Grenzen der regionalen, wirtschaftlichen oder etnischen, sogar physisch-geografischen Gebiete.

Durch Gestaltung der Nationalstaaten, beziehungsweise durch die Abgrenzung ihrer inneren Verwaltungsgebiete besaen die Grenzen immer mehr wichtige Rollen, da die Staaten, bzw. ihre inneren regionalen Einheiten (Land, Komitat, Kreis usw.) ihre räumliche Legitimität dadurch erreicht haben.

Die heutigen Staatsgrenzen folgen mehr oder weniger den Linien der vom Mittelalter herausbildenden Siedlungsgrenzen und man hatte auch bei der Ziehung der Grenzen selten Siedlungen oder Siedlungsverwaltungsgebiete durchgeschnitten.

* Dr., Prof., Geographical Research Institute, Hungarian Academy of Sciences, Andrassy ut 62, Budapest, Hungary. 
Die Grenzenziehung nach dem ersten und zweiten Weltkrieg nahm dies schon weniger in Betracht und die neuen Grenzen verschnitzerten oft Siedlungs- und Verwaltungsgebiete, funktionelle und regionale Einheiten. Daraus folgte, da die Forschung und Planung der gerade betreffenden Länder zwischen den zwei Weltkriegen und nach dem zweiten Weltkrieg nicht wenig Energie auf die Mäigung der negativen Wirkungen der neuen Grenzen angewendet hat. Diese Bestrebungen erzielten in erster Linie, da die zerfallenen, wirtschaftlich-gesellschaftlichen Räumlichkeiten, städtische Regionen in die räumlichwirtschaftliche Struktur ihrer Länder integriert werden sollten. Dieser Vorgang hat sich auch bis heute nicht vollendet, er wurde sogar durch die politische Umordnung von Mittelund Osteuropa von den bisherigen das allerwichtigste, internationale Problem. Und zwar aus zwei Gründen: einerseits, weil die unerlaliche Bedienung der räumlichen Legitimität der neuen Länder die Festsetzung der Grenzen ist, andererseits, die neuen, regionalen Entwicklungsprozesse in Europa, die auf internationaler Zusammenarbeit beruhende regionale Planung erzwingen, welche Planung von den politischen Grenzen ein bichen unabhängig ist, zugleich aber bedingt die Zusammenarbeit eine genauso räumliche Legitimität. Diese zwei Prozesse sind nur dem Anschein nach im Wiederspruch.

Die Problematik der Forschung und der räumlichen Planung der grenznahen Gebiete trat besonders nach dem zweiten Weltkrieg in den 70-er Jahren in den Vordergrund, teils im Zusammenhang mit der westeuropäischen Integration, teils im Zusammenhang mit dem wirtschaftlich-gesellschaftlichen Abbau der neuen politischen Grenzregionen (Grenze BRDDDR). Es wurde offenbar, da die sich historisch geformten und die durch neue Grenzen künstlich geteilten wirtschaftlichen Regionen als, städtische Einzugsgebiete von sich selbst nicht lebensfähig sind, zugleich aber ihre Integration in andere räumlich-strukturelle Einheiten oder ihr Aufrechterhalten im gleichen wirtschaftlich-gesellschaftlichen Niveau mit immer gröeren Kosten verbunden sind. All das warf auf die durch. gegenseitige Vorteile basierende Entwicklung der grenznahen Gebiete einen Schatten auf.

In den 1970-er Jahren schien es so, da die auf bilateralen Vereinbarungen ruhenden Entwicklungsprogramme fähig sind, die Sorgen der Entwicklung der Grenzgebiete zu lösen. Es ist allbekannt, da es zahlreiche Vereinbarungen, gemeinsame Programme in deutschfranzösischer, deutsch-österreichischer, österreichisch-italienischer Relationen zustande kamen, die die sich aus der Nähe der Grenze ergebende Verschlossenheit oder die gesellschaftliche Spannung auflöste und der lokalen Regionalentwicklung einen weiten Raum eröffnete.

Auch unter den sogenannten sozialistischen Ländern gab es ähnliche, die grenznahen Gebiete betreffende Entwicklungsprogramme: zum Beispiel in tschechoslowakisch-ungarischer Relation (Bos-Nagymaros), in ungarisch-sowjetischer Relation (Umladestation Zahony), um nur die nur Ungarn betreffende Entwicklungsprogramme zu erwähnen.

Diese auf bilateralen Vereinbarungen ruhende, auf die Grenzgebiete beziehenden Forschungen und Entwicklungspläne sind zweifellos nützlich für die Mäigung oder für die 
Lösung der Probleme einzelner Grenzgebiete. Die können aber die freie und abgestimmte Entwicklung der groen europäischen Regionen ähnlicher Gegebenheiten nicht ersetzen. Dieses Erkenntniss hat die regionalen Programme für Zusammenarbeit der einzelnen Länder und Landesteile (zum Beispiel Alpen-Adria) ins Leben gerufen, denen bilaterale Vereinbarungen etwa vorangegangen sind, beziehungsweise deren Tätigkeitsfelder und Tendenzen eingepasst worden. Ungarn ist am Anfang dieses Prozesses, da die politische Veränderungen im Jahre 1989 hoffentlich auch in den Ländern von Ost-Mitteleuropa das regionale Denken, die regionale Forschung und Planung über die Grenzen hinaus ermöglichen wird.

\section{DIE PROBLEMATIK DER GRENZGEBIETE IN UNGARN}

Aus der mit dem Friedensvertrag von Trianon fixierten heutigen Grenzlinie Ungarns ist nur der Flu Drava (Drau) als ein historisch geformtes, Regionen mit eigenartiger wirtschaftlich-gesellschaftlicher Entwicklung getrenntes "vereinbartes" Grenzgebiet. Es wurden zwar bei der neuen Grenzmarkierung Versuche gemacht, da die Grenzen natürlichen Landschaftsregionen folgen sollten, zum Beispiel an der österreichisch-ungarischen Grenze dem Koszegi-Gebirge oder an der tschechoslowakisch-ungarischen Grenze der Flulinie der Donau oder Ipoly (Eipel). Aber auch die zerschnittenen wirtschaftlichen und gesellschaftlichen Einheiten waren, insmer ein bedeutendes Problem Ungarns. Vor allem wurde die Umgestaltung des tausendjährigen Komitatssystems erfordderlich, da Komitatszentren (Sopron, Balassagyaramat, Gyula usw.) ohne Komitate blieben und auch umgekehrt Komitate (Abauj, Gömör, Bihar, Bacs usw.) ohne Zentren blieben. Diese aufgeteilten Komitate funktionierten mehr oder weniger als wirtschaftlisch-gesellschaftliche funktionelle Einheiten (im Verhältnissystem Zentrum - Peripherie) und sie waren nicht blo Verwaltungsgebiete. Infolgedessen gerieten diese geteilen funktionellen Einheiten in Ungarn bzw. auf dem Gebiet der Nachbarländer in eine funtionell periphere Lage.

Die Problematik der Grenzgebiete wurde also zwischen den zwei Weltkriegen in Ungarn hauptsächlich als Raumadministrations- und Verwaltungsproblem, deswegen wurden in den meisten geographischen, juristischen und Raumentwicklungsstudien die räumliche Umgestaltung der Verwaltung behandelt (Z. HAJDU, 1993) und neue Vorschläge veröffentlicht (I. BIBO).

Mit der Verstaatlichung der Industrie und des Tertiärsektors nach dem zweiten Weltkrieg, mit der Umorganisation der Landwirtschaft konzentrierten sich die wirtschaftlichen Ressourcen insofern, da die Verarmung der grenznahen ländlichen Gebiete, der Abbau der lokalen Gesellschaften am den Anfang der 1970-er Jahre kritisch geworden sind. Die Lage war besonders spannend entlang der jugoslawischen und österreichischen Grenze, die durch die diskriminierte Innenpolitik der 50-er Jahre bzw. in den Jahren nach 1956 besonders betroffen wurden. Es hat an der Lage dieser Gebiete auch nicht viel verändert, da sich eine Liberalisierung und Dekonzentration ab Anfang der 70-er Jahre in der Wirtschaft zeigte. 
Die Beachtung der Forschung und Planung wandte sich den grenznahen Gebiete zu und auch bilaterale Vereinbarungen auf verschiedenen Ebenen kamen mit den Nachbarländern im Bezug auf die Minderung der Probleme der Grenzgebiete zu stande (neue Grenzübergänge, die Erleichterung der Reisen, der Ausbau der wirtschaftlichen Kooperationsbeziehungen usw.). Auch schon diese Erleichterungen haben der Entwicklung solcher grenznahen Siedlungen wie Sopron, Lenti, Barcs, Zahony, usw neue impulse gegeben.

Die Forschung im österreichisch-ungarischem Grenzgebiet (P. BELUSZKY-M. SEGER 1992), die sich beiden Seiten des Grenzgebietes zuwandte und auch eine ausführliche Analyse mancher ausgewählter Siedlungen durchführte, bewies, da sich voneinander wesentlich verschiedene wirtschaftliche und gesellschaftliche Strukturen auf den beiden Seiten der Grenze in den letzen 70-er Jahren ausgestaltet haben. Die lokal-regionalen Einheiten entlang den Grenzen können allmählich funktionelle Räume werden, wenn sie auch äuere Impulse erhalten werden. Der GM-Betrieb in Szentgotthard scheint auch das zu beweisen. Damit gelang es, eine solche lokale regionale Entwicklung in Gang zu setzen, womit beide Seiten der Grenze entsprechend entwickelt werden.

\section{NEUE DIMENSIONEN DER ENTWICKLUNG DER GRENZNAHEN GEBIETE}

Die Grundlage der obigen, auf bilateralen Vereinbarungen basierende Entwicklung ist die wirtschaftliche Beteiligung, die Relität des Ausbaus der lokalen Raumbeziehungen und nicht zuallerletzt das politische Vertrauen von der Seite der betreffenden Länder.

Es erschienen aber auch neue Möglichkeiten für die Entwicklung der grenznahen Gebiete innerhalb des europäischen Integrationsprozees, in dem die komparativen Vorteile der einzelnen (bestimmten) Gebiete, Regionen schon zur Geltung kommen, da die politischen Grenzen nicht mehr Hemmungsfaktoren sind. Das beweisen auch die ostmittel-europäischen Raumbeziehungen nach der Grenzeröffnung im Jahre 1989, in denen solche regionalen Beziehungen wieder lebendig werden, die zwar schon früher jahrhundertelang funktionierten, aber in den letzten Jahrzehnten wegen der politischen Verhältnisse verborgen worden waren.

In den Jahren 1988-1993 weiterte sich der tägliche Einzug von Wien wieder auf Westungarn aus, bis zur Linie Szombathely-Gyor; der tägliche Einzug von Preburg (Pozsony) breitet sich auf das ungarische Gebiet des ehemaligen Moson-Komitates, der Einflu von Gyor wurde auch zugleich bemerkbar im südlichen Teil des slowakischen Tieflandes. Das räumliche Beziehungssystem zwischen dem Zentrum und der Peripherie gestaltet sich gesetzmäig neu, wenn es künstlich nicht gehindert wird, weil eine objektive Gesetzmäigkeit in den funktionalen Systemen ist, da man sich nach der Minimalisierung der Entfernungen strebt.

Die Bildung, Neugestaltung oder Vertiefung der Raumbeziehungen der Grenzgebiete ist im Interesse der beiden Seiten, weil während, das von einer Seite, die Funktionen der 
bestimmten Siedlung verstärkt, räumlich ausbreitet bzw. differenzierter macht, und dadurch die Netzposition der Siedlung stabilisiert. Ihr zentrales Merkmal kommte auf Grund der inneren regionalen Entwicklung (zum Beispiel Szentgotthard), solange die Verschlossenheit der ländlichen Siedlungen auf der anderen Seite bestehend war, und sie nicht die Nähe der städtischen Funktionen geniessen konnten nicht zum Ausdrick kommen. Die grenzbeziehungen weisen nicht mehr etnische, religiöse usw. identitäten aus, den sie werden durch lokale, regionale Wirtschaftsinteressen ersetzt.

Ich meine, die neue europäische Entwicklung zeigt diese Tendenz, deshalb sind die jenigen Versucher groer Bedeutung, die im mehreren Ländern regionale Entwicklung fördern, zum Beispiel das Erwähnte Alpen-Adria, Karpaten-Region (J. TOTH, 1993) Projekt usw. Die Schwäche der Verwirklichung dieser Programme ist es noch heute die Unsicherheit der räumlichen Identitäten (Selbstverwaltungen, Verwaltungseinheiten, sogar Grenzprobleme bestimmter Länder) in den ostmittel-europäischen und noch mehr in den osteuropäischen Makroregionen.

Es ergibt sich aus der Transitlage Ungarns ausghend, ein grundlegendes Interesse für die Offnung der Grenzen, die Neugestaltung alter funktionalen Raumbeziehungen und um auf diesen makro- und mikro- regionalen Wirtschafsbeziehungen neu zugestalten. Das bildet sich theoretisch notwendigerweise aus, weil die räumlichen Gesetzmäigkeiten der Markwirtschaft zur Geltung kommen werden, aber auch weil man aus der Kenntnis der Raumprozesse weiss, dass men die Entwicklung und Selbstentwicklung der grenznahen Gebiete beschleunigen werdenmus.

Es gibt heute drei Typen der Entwicklung der grenznahen Gebiete in Ungarn zu bemerken: - Siedlungen bzw. Räume, die interregionalen Beziehungen vermitteln; - die Entwicklung aufgrund der Beziehungen der Grenzregionen; - lokal-regionale Beziehungssysteme.

Die "Anspannung" Ungarns in die neue europäische regionale Entwicklung kann das Folgende sein:

- Die Möglichkeit das Karpatenbeckens zu einer Wirtschaftsregion zu machen mit einem Fragezeichen zu versehen, auch dann nicht, wenn man das heute nicht illusorisch betrachtet. Die Bedingungen der wirtschaftlichen Selbstentwicklung der Region sind nämlich gegeben, da die grundlegenden Energie und Rohstoffquellen zur Verfügung stehen, der Weg und historisch- wirtschaftlich-gesellschaftlichen Entwicklung und der Entwicklungsstand ähnlich sind. Wenn die wirtschaftliche Entwicklung grundlegend unter die Lenkung der internationalen Prozesse gerät und das selbstverwaltende innere wirtschaftliche Raumbeziehungssystem der Region zur Geltung kommen kann, wird diese wirtschaftliche in weiter Zukauft zur Realität. Für diese Wirtschaftsregion bedeutet die Zusammenseit ein Tor im die Welt, bzw. Adria. So wird die Rolle Sloweniens hochbewertet. Deshalb ist meiner Meinung nach im grundlegenden Wirtschaftsinteresse eine enge regionale Zusammenarbeit Ungarns, Sloweniens und der Slowakei. Ich bin überzeugt, da auch Ukraine und Rumänien an der Wirtschaftsentwicklung der Region interessiert werden, dadurch wird ja der Anschlu 
an die wirtschaftliche "Achse" London-Benelux-Staaten-Süd Deutschland-Wien bzw. Preburg (Poznosy) - Budapest ermöglich. Die Entwicklung dieses interregionalen wirtschaftlichen Beziehungssystem Richtung West -Osten scheint langläufig zu sein.

- Wir müssen auch zugleich sehen, da sich die Beziehungen Nord-Süden und Nordosten-Süden nach der Grenzeröffnung belebt haben. Besonders augenfällig wurde die Verstärkung des Verkehrs der altertümlichen "Bernsteinstrae", durch die die polonischtschechischen und slowakisch-ungarisch-slowenischen und norditalienischen Gebiete auf eine mögliche Wirtschaftsachse aufgereiht haben. Die Möglichkeit dieser Raumbeziehung bedingt wieder die engere Zusammenarbeit der erwähnten drei Länder, die auch wirtschaftlich-gesellschaftliche Entwicklung der betreffenden Grenzräume notwendigerweise mit sich bringt.

- Aus dem Gesichtspunkt des Aufrechterhaltens und Verstärkung der östlichen Beziehungen Ungarns ist die Vermittlung der Beziehungen zwischen Ukraine und dem Balkan äuerst wichtig (Zahony-Szeged), die sich nach 1989 bis zum Ausbruch des Balkankonflikts auch belebt hat.

Eine wichtige Aufgabe der geographischen Forschungen kann also die Aufdeckung der neuen regionalen Entwicklungsmöglichkeiten des Kontinenten sein.

\section{RAZVOJNE MOŽNOSTI V OBMEJNIH OBMOČJIH MADŽARSKE}

\section{Povzetek}

S podržavljenjem industrije in terciarnega, pa tudi primarnega sektorja po drugi svetovni vojni, je v obmejnih območjih Madžarske prišlo do kritičnega osiromašenja, posebej ob jugoslovanski in ob avstrijski meji. Šele v sedemdesetih letih se je začelo stanje izboljšsvati zaradi dekoncentriranega razvoja in z odpiranjem meja proti zahodu in jugu. $\mathrm{V}$ tem smislu je nujno izvajati takšne gospodarske dejavnosti, ki bodo vzpodbujale razvoj obmejnih območij tudi s prekomejnim sodelovanjem.

V obdobju 1988-93 se je močno póvečal vsakodnevni vpliv Dunaja vse do črte SzombathelyGyör, iz Bratislave v bivši Komitat Mason in vpliv Györa na južne dele slovaške ravnine. Stiki niso več le na religiozni in etnični osnovi, temveč vse bolj na lokalnih in regionalnih gospodarskih interesih.

Na Madžarskem gre za tri razvojne tipe obmejnih območij: - naselja, oziroma območja, ki posredujejo medregionalno sodelovanje - razvoj na osnovi sodelovanja obmejnih območij - lokalno-regionalne sisteme povezovanja. 


\title{
REGIONALNI RAZVOJ SLOVENIJE V LUČI URAVNOTEŽENO- TRAJNEGA, SONARAVNEGA RAZVOJA
}

\author{
Dušan Plut*
}

Izvleček

UDK 911.3:574(497.12-04)

Izčrpanost klasičnih vsebin regionalnega razvoja in spremenjeni zunanji in notranji dejavniki zahtevajo preoblikovanje regionalnega razvoja Slovenije. Večji poudarek je potrebno nameniti ekologizaciji regionalnega razvoja in vzpodbujanja aktiviranja endogenih, regionalnih potencialov.

Ključne besede: Trajno uravnotežen razvoj, regionalni razvoj Slovenije, regionalni viri, ekologizacija razvoja, policentrizem

Abstract

UDC 911.3:574(497.12-04)

THE REGIONAL DEVELOPMENT OF SLOVENIA VIEWED AS SUSTAINABLE DEVELOPMENT

The worn out clasiccal regional development contents and the changed outer and inner circumstances demand a drastic change in the Slovenian regional development concept. An increased emphasis on ecology within regional planning is a necessity. Such an approach is going to encourage an effective use of various endogenous regional potentials.

Key words: Sustainable development, regional development of Slovenia, regional endogenous sources, ecologic development concept, poly-centric development

Bistveno spremenjeni notranji in zunanji dejavniki zahtevajo, da Slovenija oceni izhodišča in rezultate dosedanjega regionalnega in prostorskega razvoja ter temu primerno ukrepa. Osamosvojitev Slovenije spreminja njeno geopolitično vlogo, gospodarske in ostale tokove z bivšimi jugoslovanskimi republikami, meja s sosednjo Hrvaško pa zlasti vpliva na položaj in pomen slovenskih pokrajin ob vzhodni in južni meji. Vzporedno z osamosvojitvijo poteka tudi prehod v tržno ekonomijo, ki lahko brez socialnih, ekološko-prostorskih in regionalnih sestavin, s politiko skrajne liberalizacije gospodarstva, povzroči še večje regionalne razlike med slovenskimi pokrajinami.

Slovenija se je odločila, da razširi in poglobi politiko sodelovanja in vključevanja v sodobne svetovne, zlasti pa evropske povezovalne tokove. Odprtost države prinaša večji vpliv zunanjih faktorjev na regionalni razvoj Slovenije (Skica 1).

Sodobne planetarne megatrende označuje, razen poglobitev prepada med Severom in Jugom ter zloma večine socialističnih držav predvsem globalizacija in regionalizacija ter širjenje in dograjevanje paradigme sonaravnega, uravnoteženo-trajnega razvoja. Med globalizacijskimi procesi so $\mathrm{z}$ vidika razvojne strategije in regionalnega razvoja $\mathrm{v}$ ospredju:

* Dr., izr. prof., Oddelek za geografijo, Filozofska fakulteta Univerze v Ljubljani, Aškerčeva 2, 61000 Ljubljana, SLO 
Regionalni razvoj Slovenije ...

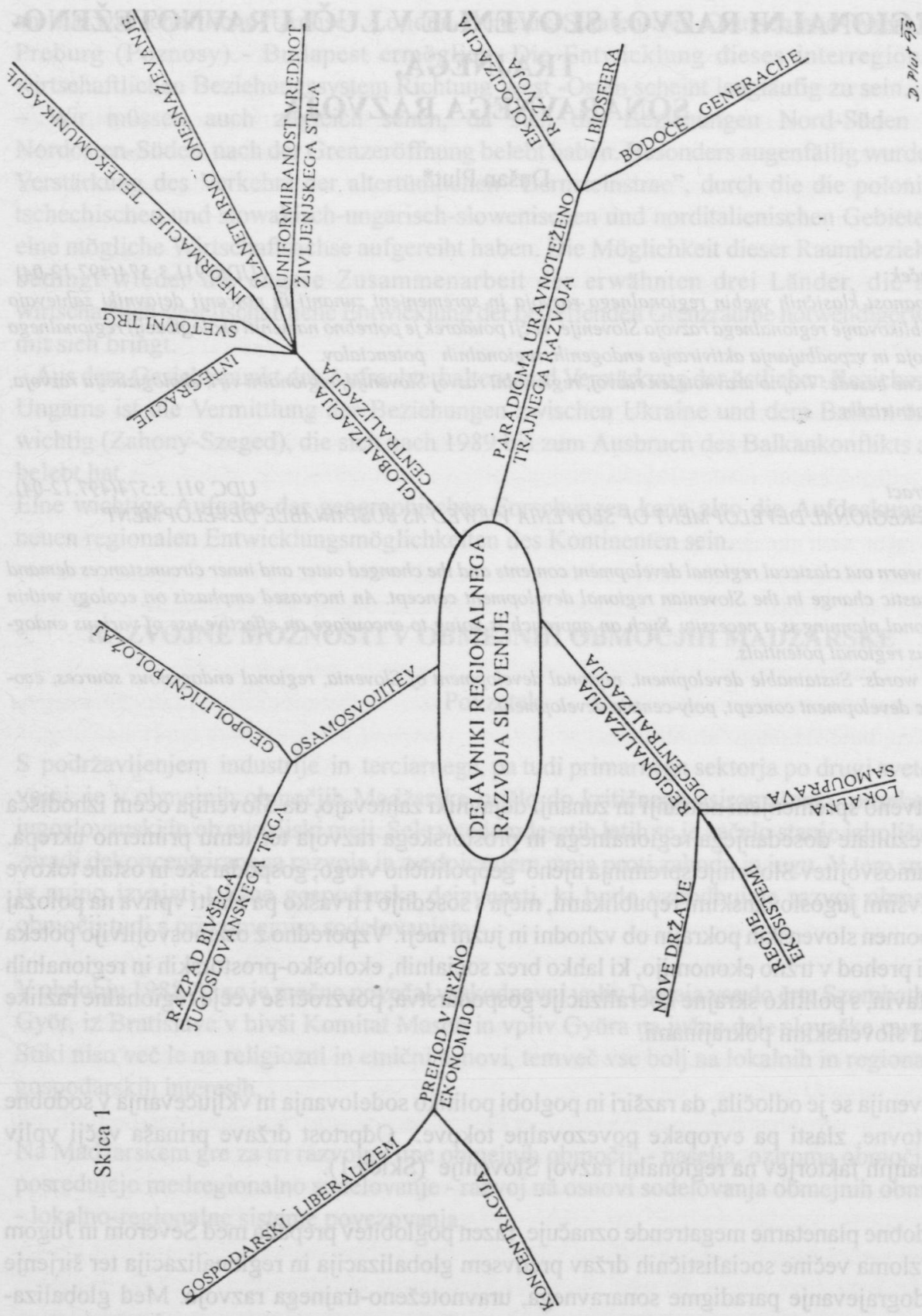


- gospodarske, prometne in politične integracije zlasti v Evropi (EU) in Ameriki (NAFTA). Z nadnacionalnimi povezovanji, rastjo mednarodnih korporacij, se seveda zožuje državna suverenost (Kennedy, 1993)

- demografska eksplozija v manj razvitih državah se nadaljuje. Vse bolj pereč je problem mednarodnih migracij, saj prednosti globalizacij (svetovni trg, prenos fleksibilnih tehnologij, informacij, znanja) ne veljajo za vse države in socialne skupine (Engelhard-Abdallah, 1992)

- izčrpavanje naravnih virov, antropogenizacija planetarnih biogeokemičnih ciklov, presežene samočistilne zmogljivosti pokrajinskih ekosistemov, izgubljanje biološke raznovrstnosti in planetarne klimatske spremembe ogrožajo preživetje človeške vrste in življenje na Zemlji kot živem planetu nasploh (Chiros, 1988, Margulis-Lovelock, 1989).

$V$ tržno prevetrenih ekonomijah visoke materialne življenjske ravni je $v$ zadnjih nekaj letih prišlo do razkoraka med do sedaj pozitivno korelacijsko povezanimi procesi povečanega BDP in naraščajočo porabo energije (Bernstam, 1991, s. 333). Vendar potekajo v globalnem smislu proizvodno-potrošni tokovi industrijsko-informacijskih držav še vedno v nasprotju z univerzalnimi planetarnimi omejitvami (prostor, prosta energija, surovine, prst, samočistilne sposobnosti) entropija in obremenitev planeta narašča. Zahodni model rastočega potrošništva, zaradi planetarnih omejitev ni sprejemljiv za vseh 5,5 milijard Zemljanov (Plut, 1991).

Po mnenju Engelharda in Abdallaha (1992) pa je proizvodno- potrošni vzorec v zadnjih nekaj letih le postal do okolja in naravnih virov manj brutalen. Med skrajnostnima paradigmama materialne rasti brez omejitev in ničelne rasti se je $v$ zadnjih nekaj letih uveljavila paradigma uravnoteženo-trajnega, sonaravnega razvoja, ki poskuša materialno dejavnost, antropogene snovnoenergetske tokove trajno uravnovešati z nosilnostjo okolja in omejenimi naravnimi viri. Kljub nekaterim poenostavitvam (n.pr. pri rabi neobnovljivih virov) pa pomeni naravno varovalno zasnovana paradigma korak naprej k planetarnoekološko uresničljivi in možni poti napredka. Uravnoteženo-trajno družbo okoljske etike naj bi po mnenju Chirasa (1988) označevalo zlasti:

- učinkovitejša in smotrna raba ter varovanje naravnih virov, ekosistemov, - reciklaža vseh neobnovljivih virov -prehod na obnovljive vire,

- raba primernih tehnologij in prehod iz cest k železnici, javnemu prevozu,

- naravi prijaznejše pridelovanje hrane in trajno varovanje rodovitne prsti, - kontrola rasti prebivalstva.

"Ekologizacija" razvoja, torej tudi regionalnega razvoja, pomeni upoštevanje termodinamičnega zakona o entropiji in univerzalnih planetarnih omejitev pri načrtovanju proizvodnje, potrošnje, bivanja in potovanj, ter upoštevanje potreb bodočih generacij in ostalih členov biosfere (Skica 1). Skladnejši regionalen razvoj dobiva s tem novo razsežnost in sestavino. Ciljema ekonomske uspešnosti in socialne pravičnosti se torej enakovredno pridružuje cilj trajnega ohranjanja dinamičnega ravnovesja, etika okolja. Regionalni razvoj dobiva oznako sonaravno in ekosistemsko zasnovanega regionalizma kot protiuteži in istočasno komplementarni entiteti globalizma. Paradigma uravnoteženo-trajnega razvoja 


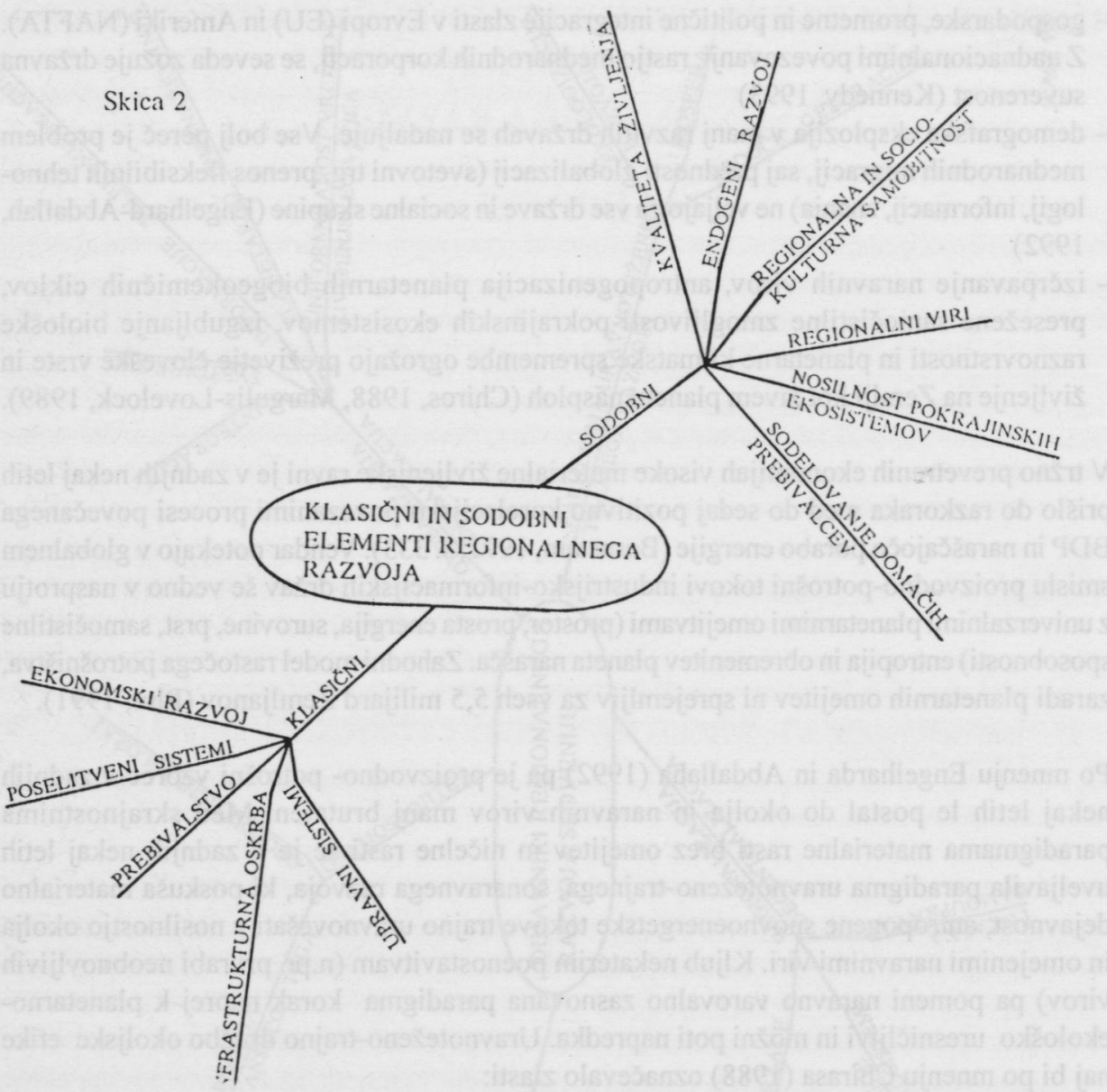

vsebuje vzvode, ki preprečujejo marginalizacijo območij in socialnih skupin, ki se ne bodo mogle prilagoditi vsem zahtevam s sodobnimi tehnologijami podprte produkcije (Dekleva, 1992). Vprašljivo pa je, če se bo "mehko" in etično zasnovana "sonaravna" paradigma lahko brez pomoči države in državljanov uspešno spoprijela $\mathrm{z}$ velikimi mednarodnimi finančnimi proizvodno- in trgovskimi združbami, ki obvladujejo vedno večji delež svetovnih finančnih in trgovinskih tokov. Prenovljena regionalna politika torej pomeni, da sta "neekonomska" cilja, ekološki in socialno-kulturni, enakovredna ekonomskemu (Loetscher et al, 1987, Duerr, 1987). Endogen razvoj, pomen regionalnih virov, sodelovanje domačega prebivalstva, decentralizacija uprave predstavljajo ob ekologizaciji regionalnega razvoja (regionalnim razmeram primerne tehnologije) temeljno dopolnilo dosedanjih ekonomističnih politik obrobnih območij (Maier, 1987; Kurz, 1991; Hahne - Maier, 1993). (Skica 2). 
Izhodišče klasičnih regionalnih politik je bilo predvsem zagotoviti vsem prebivalcem enake življenjske in delovne pogoje $\mathrm{v}$ vseh regijah. Kljub dolgotrajnemu obdobju povojne gospodarske rasti ta cilj ni bil dosežen (Hahne-Maier, 1993). V ospredju je bila pomoč države predvsem z investicijami na področju infrastrukture (promet, vodna oskrba, itd.). Podeželje Srednje Evrope je v zadnjem desetletju doživelo dramatične strukturne in funkcijske spremembe, zato potrebujemo nove prijeme in strategijo, v prvi vrsti prepoznavanje izjemnega pomena in vloge lastnih, regionalnih, endogenih virov. Zato sonaravno in regionalistično izrazitejše regionalne politike povdarjajo pomen ohranjanja pokrajinsko-ekološke, regionalne in kulturne identitete pri vzpodbujanju pretehtanega aktiviranja lastnih regionalnih razvojnih potencialov. Razen antropogenih potencialnih faktorjev regionalnega razvoja (delovna sila, kapital, infrastruktura, tržni-povpraševalni in sociokulturni kapital) se mora oceniti tudi naravni potencial, torej ekološki potencial okolja, zemljišča, pokrajine (Kurz, 1991, s. 16). Le-ta je sestavljen iz surovinskega, vodnega, biotskega potenciala donosa (kmetijstvo, gozdarstvo), klimatskega, potenciala oddiha, naravovarstvenega (regeneracijski in regulacijski) in potenciala za pozidavo. Ekološki potencial podeželja zmanjšuje tako pretirana raba naravnih virov kot odlaganje različnih odpadkov. Sonaravna raba virov pa pomeni rabo le do nivoja ohranjanja brez negativnih vplivov na okolje (Hahne-Maier, 1993). Središčna vloga domačih virov označuje regionalni koncept razvojne politike, ki ga Maier (1987) imenuje regionalna samobitnost. V ospredju je ekonomsko optimalna in ekološko trajna raba domačih virov, integrirano reševanje gospodarskih, ekoloških, socialnih in kulturnih problemov regije in aktivno sodelovanje domačega prebivalstva. Taki razvojni politiki odgovarja policentrizem kot način upravljanja in oblika razvojne politike, ki jo izvaja vlada na področju poselitve, razmestitve gospodarskih zmogljivosti, javnih služb in uprave (Vrišer, 1989, s. 11). Sprejetje in udejanjanje ekologizirane in trajno uravnotežene razvojne politike pomeni korekcijo policentrizma predvsem glede rabe naravnih virov, urejanja prostora in okolja v smeri sonaravnega, okoljevarstvenega policentrizma.

V zadnjih letih pa je postal regionalizem tudi dejavnik politične organiziranosti in civilne družbe, protest proti "zunanjemu in notranjemu kolonializmu". Torej poudarjanje regionalne avtonomije in ekosocialne tržnosti nasproti uniformirani in globalni, skrajno liberalni tržni gospodarski doktrini.Center za regionalni razvoj in okolje OZN (UNCRD, 1993) označuje sodobno zasnovan regionalni razvoj kot proces strukturnih sprememb $v$ okviru posameznega območja države, ki med drugim deluje $v$ korist manj priviligiranim socialnim skupinam in vključuje v procesu spodbujanja regionalnih zmogljivosti tudi okoljske premisleke in iskanje najbolj primernih aktivnosti glede okolja in naravnih virov. Regionalni razvoj mora doseči dva temeljna cilja: izboljšanje življenske ravni in izboljšanje $\mathbf{v}$ degradiranih območjih ter ohranitev kvalitete okolja $v$ zdravih nedegradiranih območjih. Upoštevanje načel sonaravnosti v razvoju pomeni, da je potrebno za vsak pokrajinski ekosistem, pokrajino, izdelati razvojni načrt, ki bo dosledno upošteval svojstveno pokrajinsko-ekološko občutljivost in nosilnost okolja.

Slovenija se kot samostojna država torej nahaja pred izjemno zahtevno in daljnosežno izbiro 
primernega koncepta regionalnega razvoja, prostorske razvojne politike. Pregled dosedanjih konceptov kaže da smo pred izborom četrtega koncepta razvojne politike. Vrišer (1989, s.11) označuje koncept Dravske banovine (pred drugo svetovno vojno) kot udejenjanje decentraliziranega modela razvoja, ki je podpiral naravno-geografsko in poselitveno prilagojen razvoj industrije in urbanizacije Slovenije. Po drugi svetovni vojni je B. Kidrič ta koncept zavrgel in se zavzel za koncept koncentracije gospodarstva, razvoj mest, deagrarizacijo in praznjenje podeželja z izrazito centralizacijo uprave. Leta 1958 je prišlo do uvedbe komunalnega sistema, decentralizirne uprave in gospodarstva, a neenakomernega regionalnega razvoja (zlasti rast Ljubljane in Gorenjske). Leta 1972 je bila sprejeta politika skladnejšega regionalnega razvoja, ki je le nekoliko zmanjšala regionalne razlike, zelo izrazite pa so ostale predvsem na občinski ravni. Policentrizem ni doživel še večje konkretizacije, ker ni bilo vmesne teritorialne-upravne stopnje (središča regij), celotno povojno obdobje pa ne glede na centralistično ali decentralistično razvojno politiko označuje vse do srede oziroma do konca 80 let izrazitost degradacijskih procesov, ki so v urbano-industraliziranem, dolinsko-kotlinskem tipu izoblikovali nov tip, pokrajinsko - ekološko degradirane in danes tudi ekonomsko depresivne regije (Zasavje, Mežiška dolina, Jesenice, itd.) (Plut, 1987). Predvsem zaradi intenzivne industrializacije in potrošne rabe energije ter surovin je stopnja izčrpavanja naravnih virov in polucijska bremenitev dosegla bistveno višjo stopnjo kot bi pričakovali glede na dosežen materialni standard.

Razen degradacijskih grehov preteklosti in upadanja življenske ravni se $\mathrm{v}$ trenutku prehoda $\mathrm{v}$ četrti koncept regionalne politike srečujemo s problemom pomanjkljive zunanje in notranje prometne povezanosti z Evropo (ceste, železnice), z drugimi slabostmi pretirane industrializacije ter s problemi majhnih kmetij. A tudi z nekaterimi pozitivnimi izkušnjami $\mathrm{v}$ praksi sicer le delno udejanjenega policentričnega regionalnega prostorskega razvoja in tradicionalne odprtosti meja, $\mathrm{v}$ visoki fazi razkroja agrarne in oblikovanja prostorske strukture urbane družbe (Klemenčič, 1992). Iskanje odgovora in izbor koncepta poselitve, razvojne strategije $\mathrm{v}$ Sloveniji je tesno povezano $\mathrm{z}$ načeli uravnoteženo - trajnega razvoja. Med vrsto vprašanj in odločitev bo eno izmed osrednih: ali bo Slovenija predvsem izkoristila svoj geografski položaj v smeri krepitve prometno/proizvodne funkcije ali pa bo več pozornosti posvetila ponudbi obsežnih območjih še kvalitetnega naravnega okolja oziroma ekološki paradigmi prostorskega razvoja (Piry,1992, s.99).

Avtor sodi, da nadaljna industrializacija zaradi omejenih naravnih virov (surovine, energija), prostorske in ekološke zahtevnosti in ostalih razlogov ne more biti temeljni kamen kvalitetne ekonomske rasti Slovenije, prenapeta pa je tudi hitra in enosmerna preusmeritev v tržno in sezonsko zelo občutljiv turističen razvoj. Glede na gospodarsko sestavo, geografske vire, prometni položaj in potrebe po skladnejšem regionalnem razvoju bo potrebno poiskati ravnovesje med okolju prijaznejšimi industrijskimi panogami (zlasti srednja in manjša podjetja s postopnim opuščanjem surovinsko - energetsko zahtevnih proizvodnih procesov) in vzporedno rastjo malega gospodarstva, mehkega turizma, kmetijstva in storitvenih dejavnosti. Potrebna je boljša prometna in informacijska povezanost, $\mathrm{v}$ skladu $\mathrm{z}$ lastnimi potrebami in nosilnostjo slovenskih pokrajin. 
Odprtost prinaša tudi izpostavljenost prostorsko - demografsko in kapitalsko majhne Slovenije, njene ranljivosti v procesu internacionalizacije gospodarstva. $Z$ možnostjo, da ob popolni liberalizaciji in "divjemu" lastninjenju mednarodni kapital preprosto kolonizira Slovenijo ali pa ji "milostno" prepusti položaj prometnega koridorja in odlagališča ekološko nevarnih, surovinsko - energetsko intenzivnih, zastarelih tehnologij in proizvodnih postopkov. Obrobnim regijam pa ob kratkotrajno profitno donosnemu vlaganju določi le vlogo opazovalca, ujetega v nizko inovativnost, pasivnost in pričakovanje "odrešilne" vloge zapoznele industrializacije in ostalih prijemih le klasično zasnovanega regionalnega razvoja. Razmerje center - periferija je še vedno eminentno vprašanje regionalne politike Slovenije (Mušič, 1992).

Regionalni razvoj samostojne Slovenije naj bi organsko vključil sodobne globalizacijske in regionalizacijske megatrende sveta, koncept sonaravnega razvoja, izhajal pa naj bi iz geografskih stalnic in geografskih spremenljivk Slovenije in njenih regij. Temeljne geografske stalnice Slovenije so (Skica 3) (Gams, 1992, Plut 1987):

1. Lega v Srednji Evropi, na stiku z Južno in v bližini JV Evrope.

2. Stik štirih evropskih makroregij (Alpe, Panonska kotlina, Dinarsko gorstvo, Sredozemska kotlina).

3. Goratost oziroma razčlenjenost ozemlja.

4. Skromni in izčrpani naravni viri.

5. Slabi pogoji za poljedelstvo (boljši na mladokvartarnih naplavinah in na terciarnem gričevju).

Naštete geografske stalnice opredeljujejo Slovenijo kot pokrajinsko zelo pestro evropsko državo s poudarjeno kraškostjo in prevlado zahodne zračne cirkulacije. Temeljne geografske spremenljivke Slovenije pa so (Klemenčič, 1992; Klemenčič-Genorio, 1993; Vrišer, 1990, Plut, 1987):

1. Geopolitična in prometna lega na stiku različnih narodov, držav in evropskih regij ter slaba zunanja in notranja prometna povezanost

2. Razpršena poselitev, migracije, $\mathrm{z}$ zgostitvijo prebivalstva in dejavnosti $\mathrm{v}$ dolinskokotlinskem svetu ter suburbanizacija

3. Poudarjena industrializacija in deagrarizacija s slabše razvitimi uslužno-oskrbnimi dejavnostmi

4. Snovno-energetske obremenitve ranljivejših pokrajinskih enot in zanemarjen regionalni naravni potencial

5. Odprta meja in prisotno meddržavno regijsko sodelovanje

6. Razvite zasnove policentričnega regionalnega razvoja

Optimalno, tudi sonaravno zasnovan regionalni razvoj Slovenije kot države in vseh njenih regij se mora na eni strani prilagoditi geografskim stalnicam in bodočim potrebam primerno korigirati geografske spremenljivke (Skica 4). 
Regionalni razvoj Slovenije ...

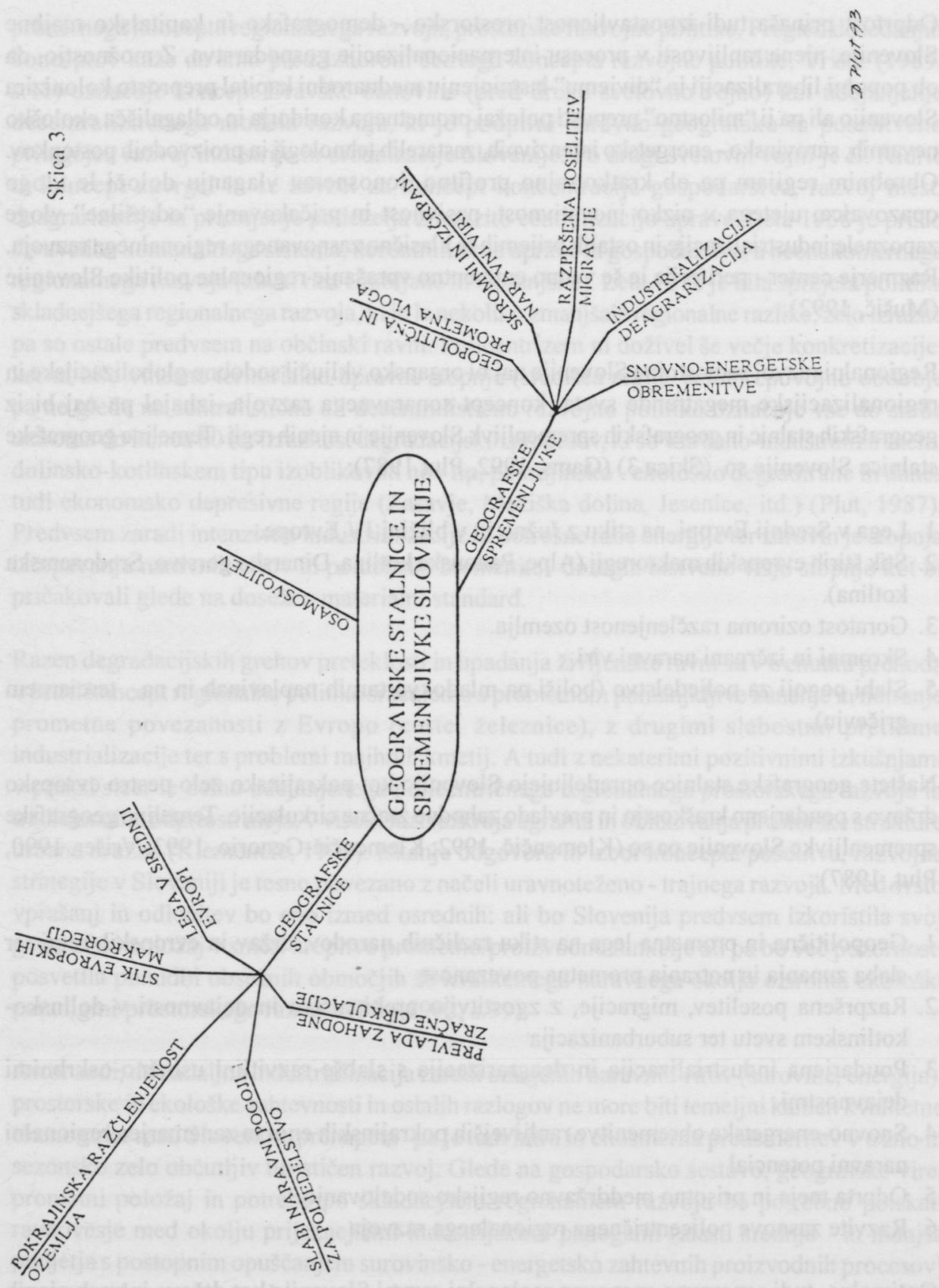


Regionalni razvoj Slovenije ...

1. Zato je neobhodna analiza in vrednotenje podcenjenih regionalnih virov, predvsem naravnih (Plut,Piry,Černe, 1984) in ekosistemska ocena njihove ranljivosti, torej pokrajinskoekološko in socialno-estetsko vrednotenje tudi neekonomskih funkcij naravnih virov in pokrajin Slovenije (proizvodnja čistega zraka, vode, izravnalna funkcija odprtega prostora, preprečevanje erozije prsti in poplav, pomen biološke raznolikosti zlasti $v$ zavarovanih območjih itd).

2. Razpad druge Jugoslavije in nastanek slovenske države prinaša velike spremembe tudi kih virih Slovenije, pomembne sestavine regionalnih virov in s tem regionalne politike. Zaradi politike ekstenzivnega zaposlovanja je Slovenija prevzela preveč pretežno nekvalificiranih delovnih viškov prebivalstva bivših drugih jugoslovanskih republik. (Jakoš, 1992, s. 109). Presežek števila priseljenih prebivalcev nad odseljenimi se je v posameznih letih približal številki 10.000 , kar je pomenilo že do $40 \%$ celotnega porasta števila prebivalcev Slovenije. Po pričetku hitrega upadanja števila rojstev po 1.1980 beležimo 1. 1990 po tridesetih letih ponovno negativen selitveni saldo, 1. 1991 je tako znašal nad 3000 prebivalcev. Srečujemo se s procesom stagnacije, s prvimi znaki prihajajočega zniževanja in pospešenega staranja prebivalstva. $V$ regionalni politiki pomenijo navedeni, za Slovenijo novi populacijski procesi, med drugim neobhodnost poudarjenega pomena znanja, izobrazbe prebivalstva, kot temeljnega razvojnega potenciala Slovenije. Tako postaja ponovno navidezno še bolj privlačna teza, da je število 6000 naselij za Slovenijo občutno preveliko. Avtor sodi, da bi zmanjšano število odročnih naselij pomenilo krčenje kulturne pokrajine (že sedaj je več kot $51 \%$ Slovenije gozdnate), zmanjšanje možnosti pridelave zdrave hrane in dodaten populacijski pritisk $v$ polucijsko obremenjena mesta rodovitnih dolin in kotlin.

3. Preko ozemlja Slovenije potekajo temeljne prometne poti v smeri SZ-JV in JZ-SV (Černe, 1993). Prometna prehodnost ozemeljsko majhne Slovenije ji daje pravzaprav kot celoti značaj obmejnosti. Ozemlje Slovenije prečkata torej dve pomembni prometni osi (MilanoLjubljana-Maribor-Budimpešta; Muenchen-Karavanke-Ljubljana-Zagreb-Istanbul). Prometno omrežje povezuje tudi funkcije slovenskih mest, ki so ključni nosilci gospodarskega in družbenega razvoja učinkovitejše urbano proizvodne zgostitve in vključevanja Slovenije v širši evropski prostor (Jazbinšek-Šarec, 1991). Klub vrsti pokrajinskih, ekoloških, kmetijskih in vodnooskrbnih zadržkov bo potrebno z vso ekosistemsko pretehtanostjo zgraditi omejen sistem avtocest. Vendar prioritetno v službi policentrično zasnovanega regionalnega razvoja Slovenije (Dekleva, 1992), in ne kot najkrajše koridorje mednarodnega prometa $\mathrm{z}$ vsemi škodljivimi prostorsko-ekološkimi posledicami (n.pr. Savinjska dolina, Dravsko-Ptujsko polje, Vipavska dolina), ob istočasni gradnji in posodobitvi regionalnega cestnega omrežja(n.pr. Posočje-Ljubljana-TrbovljeKrško; Metlika-Novo mesto-Celje-Kozjansko; Dravograd-Maribor, Žalec-Koroška). Tudi za potrebe pretehtanega razvoja turizma naj vzporedno $\mathrm{z}$ gradnjo kolesarskih stez in $\mathrm{z}$ avtocestami poteka posodobitev hitrega železniškega omrežja. Prometna dostopnost vseh slovenskih regij je po mnenju Mušiča $(1992, s .40)$ najvažnejša prvina skladnejšega regionalnega razvoja za vključevanje tako obrobnih kot tudi depresivnih regij v povezan in soodvisen gospodarski in družbeni sistem Slovenije. 


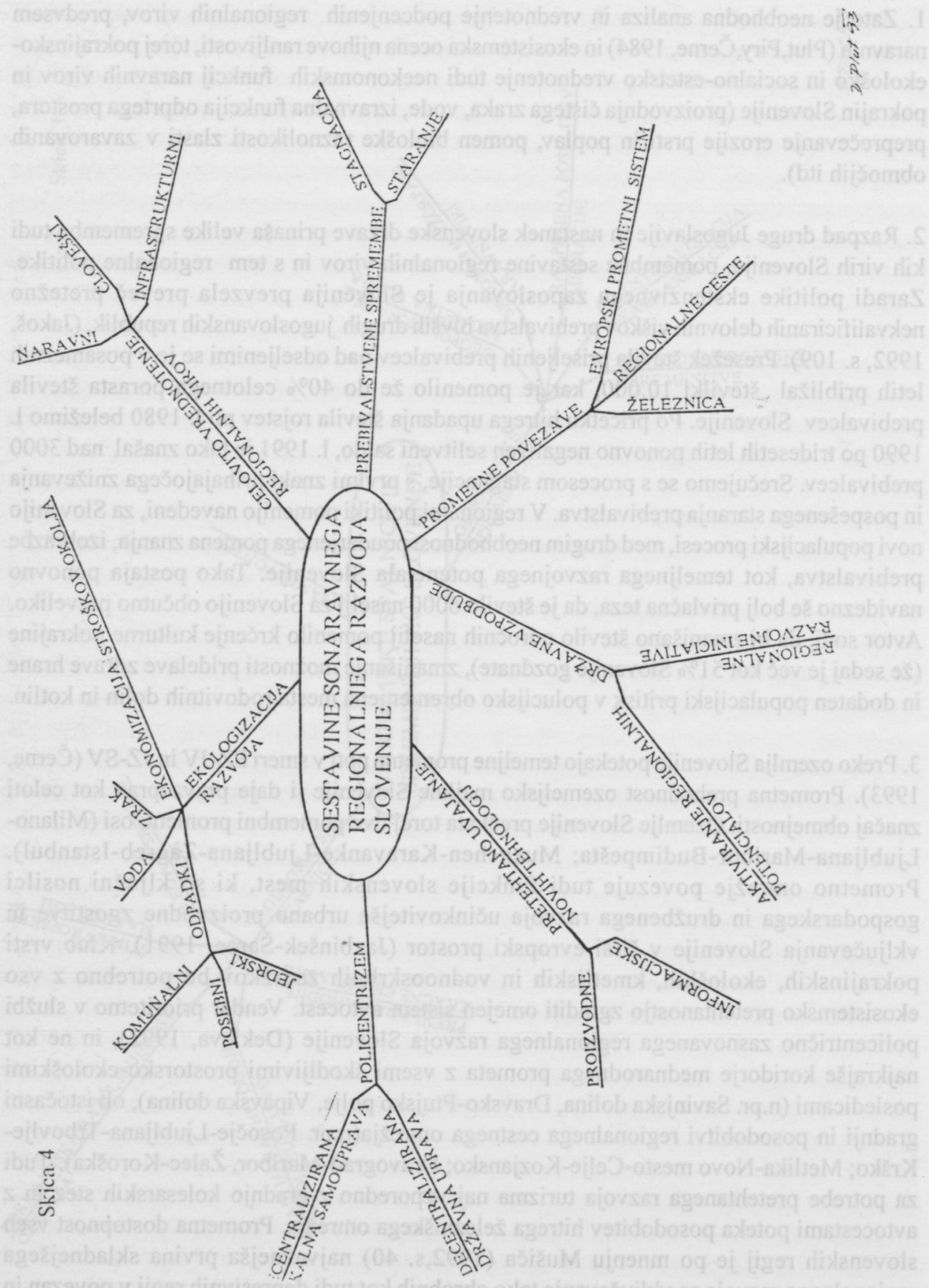


4. Kljub določenim delnim rezultatom dosedanjega vzpodbujanja razvoja v manj razvitih (kasneje označenih kot demografsko ogrožena območja) so se klasično razvojne zasnovane spodbude države inovacijsko izčrpane, privatna lastnina pa prinaša novo razvojno razsežnost in priložnost. Dosedanje razvojne spodbude države so zasnovane predvsem na enakomerni regionalni porazdelitvi finančnih sredstev na zelo obsežnih, zakonsko določenih demografsko ogroženih območjih ( $40 \%$ celotnega ozemlja države), rezultati pa so zaradi razpršenosti in neusklajenosti pičli. V spremenjene mehanizme posredne in neposredne pomoči države razvojno šibkim in pokrajinsko degradacijskim območjem Slovenije bo potrebno vgraditi predvsem spodbude za aktiviranje regionalnih in lokalnih razvojnih potencialov, pomoč lokalnim razvojnim iniciativam, rabi regionalnih virov, sonaravno zasnovanim infrastrukturnim in gospodarskim projektom. Predpogoj pa je aktivnejša razvojna iniciativa lokalnega prebivalstva, pomoč občin, večja koordinacija med različnimi vladnimi sektorji. Torej zgostitev in usklajenost kritične razvojne mase različnih spodbud v vladni agenciji in skladu za regionalni razvoj s svetovalnimi regionalnimi in občinskimi razvojnimi podjetniškoinformacijskimi centri, raziskovalnimi parki, informacijskimi in podjetniškimi mrežami. Izdelati je potrebno tudi celovitejše kriterije za dodeljevanje državnih spodbud (sokreditiranje, davčne olajšave, sovlaganje itd), ki morajo razen demografskih, ekonomskih in socialnih vključiti tudi infrastrukturne in pokrajinsko degradacijske dejavnike (kvaliteta bivanja) ter upoštevati specifičen položaj območij ob slovensko-hrvaški meji.

5. Nove proizvodne informacijske in telekomunikacijske tehnologije hkrati pogojujejo centralizacijo in omogočajo decentralizacijo. Po mnenju Mušiča $(1992, s .43)$ torej hkrati potekata procesa centralizacije z linearno zgostitvijo vzdolž glavnih koridorjev zmogljivih prometnic, istočasno pa se zelo cenijo atraktivna naravna in kulturna okolja, kvaliteta bivanja. Zelo težko je dati jasen odgovor ali bodo n.pr. nove informacijske tehnologije dovoljevale razvoj novih dejavnosti izven sedanjih centralnih naselij tudi $v$ obrobnih neurbaniziranih območjih. Vsekakor pa bo mogoče s pomočjo izboljšanih informacijskih sistemov postaviti fleksibilne proizvodne enote tudi izven dosedanjih industrijskih centrov (Stanovnik-Faleskini, 1992, s. 49). Z vidika regionalnega razvoja lahko pričakujemo, da se bo $\mathrm{z}$ uvajanjem novih tehnologij in krepitvijo regijskega gospodarstva konkurenca med slovenskimi regijami povečala, prav tako pa tudi strateška zavezništva, mreža med posameznimi regijami, tudi z regijami sosednjih držav. Umestno je opozorilo, da je tudi pri sodobnih tehnologijah potrebna njihova vsestranska temeljita ekosistemska in etična presoja. Pokrajine ob slovensko-italijanski in slovensko-avstrijski meji so glede na tehnološke evropske tokove $\mathrm{v}$ določeni prednosti pred regijami ob slovensko-madžarski zlasti pa pred regijami ob slovensko-hrvaški meji.

6. Utrditev in dopolnitev policentričnega urbanega sistema pomeni ne le ogrodje in podporo nastajajoči upravni razdelitvi Slovenije, temveč tudi neobhodno sestavino skladnejšega regionalnega razvoja Slovenije in koncepta evropsko zasnovane lokalne samouprave. Analiza sistema centralnih naselij kaže, da se je $\mathrm{v}$ zadnjih tridesetih letih okrepila predvsem vloga občinskih središč, Ljubljane in Maribora, oslabela pa so nekatera tradicionalna središča srednje mezoregionalne ravni (Vrišer, 1988, 1990). V vrsti primerov je zastalo tudi razvijanje 
omrežja nižjih centrov, kar je v večini ustrezalo občinskim središčem. Zaradi zelo razpršenega poselitvenega vzorca Slovenije in reliefnih prometnih ovir je tako široko območje Slovenije ostalo izven razvojnih vrenj, kljub drugačni besedni politiki.

Od bodočega koncepta urbanega sistema ter notranje organizacije države, javne uprave in lokalne samouprave bo $\mathrm{v}$ veliki meri odvisno, ako bomo odgovorili na izzive regionalizma. Avtor zagovarja tako decentralizacijo kot temelja lokalne samouprave (manjše občine pokrajine - država) kot dekoncentracijo državne uprave, ki dejansko omogočata uveljavitev skladnejšega regionalnega razvoja na celotnem ozemlju Slovenije. Smotrno bi bilo, da bi se sicer ločena lokalna samoupravna in javna uprava na vmesnem nivoju (pokrajina/okraji) ozemeljsko ujemale. Pestra pokrajinska podoba pretežno gorate Slovenije, potreba prebivalcev, specifičen položaj obmejnih prometno odmaknjenih in manj razvitih pokrajin Slovenije, pojmovanje okrajev kot naravnih in ne kot administrativnih območji, naraščajoča regionalna identiteta, predstavljajo argumente za izoblikovanje okoli 20-30 upravnih okrajev, njihove upravne izpostave $v$ vseh sedanjih občinskih središčih in določeno upravno vlogo po dogovoru tudi v novih občinah. Zavračanje pokrajin in regij kot obvezne vmesne stopnje in istočasno oblikovanje majhnih občin bi pomenilo močan centralizacijski impulz vrsto argumentov in proti argumentov pa sprožajo tudi variante o manjšem številu okrajev. Avtor pa sodi glede na sodobne regionalistične trende $v$ Zahodni Evropi (npr. Italija) da bo morda $v$ bodočnosti postal aktualen tudi še nivo slovenskih dežel (Štajerska, Gorenjska, Primorska, Dolenjska Osrednja Slovenija). Upravne reforme v evropskih državah so v zadnjih desetletjih povsod težile $\mathrm{k}$ večji racionalnosti uprave in $\mathrm{v}$ ta namen so uveljavili večje občine in okraje (Vrišer, 1993). Razen pokrajinske razdrobljenosti Slovenije je prav nerazvita prometna infrastruktura temeljni argument, da je $v$ tem trenutku smotrno vspostaviti nekoliko večje število upravnih okrajev in jim s tem omogočiti tudi enake startne možnosti na trgu ponudbe in povpraševanja ter se izogniti čerem regionalnega centralizma. Modra država regionalizmu prisluhne, saj je odraz želj in potreb njenih državljanov.

7.Ekonomizacija vseh stroškov proizvodnje (tudi okoljaških), preprečevanje in sanacija degradacije pokrajinotvornih sestavin in območij, torej ekologizacija regionalnega razvoja je tudi mednarodna obveza Slovenije, zlasti do sosednjih držav in seveda obratno. Tako je prispevek Slovenije k planetarnemu segrevanju glede na število prebivalcev in ozemlje nad svetovnim povprečjem.

V letu 1991 je Slovenija v ozračje emitirala več kot 12 milijonov ton CO2 oziroma okoli $6.100 \mathrm{~kg} / \mathrm{preb}$. (svetovno povprečje okoli $4.500 \mathrm{~kg} / \mathrm{preb}$./letno). Natančna bilanca o izvozu in uvozu SO2 oziroma žvepla za Slovenijo sicer še ni bila izračunana. Primerjava s podatki katastra emisij SO2 za Evropo in Slovenijo pa nedvomno kaže, da izvažamo večjo količino žvepla kot jo sprejmemo (Onesnaženost zraka...,1992), kljub zmanjševanju emisije SO2 (1. 1985-240.000 ton; 1. 1991-180.000 ton). Ekološka sanacija slovenskih TE je prioritetna naloga. Posledice so najbolj vidne $\mathrm{v}$ propadanju gozda, saj je bilo $\mathrm{v}$ različnih stopnjah poškodovanosti v l. 1989 40\% slovenskih gozdov (Kmecl, 1990). Letna emisija SO2 na prebivalca Slovenije je 1.1986 znašala $123 \mathrm{~kg}(1.1991$ - $90 \mathrm{~kg}$ ), kar je bilo več kot šestkrat 
več kot na prebivalca sosednje Avstrije ( $19 \mathrm{~kg} / \mathrm{preb} / \mathrm{letno})$ in trikrat več kot na prebivalca sosednje Italije (36 kg/preb/letno) (Onesnaženost zraka...,1991)

Slabša se kakovost talne vode in izvirov, globalno pa umirja onesnaževanje površinskih voda (Kakovost zraka..., 1992). Pomanjkanje kvalitetne pitne vode postaja v dobro namočeni Sloveniji problem gospodarskega razvoja in vprašanje zdravja, slaba kvaliteta Mure, Drave, Save, Soče, Sotle, Kolpe, Koritnice, Notranjske Reke, Severnega Jadrana pa zahteva tudi meddržavno in medregionalno sodelovanje. V Sloveniji je morda celo 10.000 divjih odlagališč komunalnih in ostalih odpadkov, ki jih bo potrebno sanirati. Posebni odpadki se kopičijo na dvoriščih podjetij, uvajanje integralno zasnovanega koncepta ravnanja z odpadki pa je $v$ zamudi.

Radioaktivno sproščanje plinov in tekočin JE Krško je po dosegljivih podatkih pod dovoljenimi vrednostmi. Razen možnosti nesreče ali vojaškega napada (zaustavitev JE Krško zaradi nizkega preleta letal JA julija 1991) pa je dejansko največji problem nerešeno stalno skladiščenje vseh vrst radioaktivnih odpadkov. Zlasti pa izrabljenega jedrskega goriva, ki se začasno skladišči v vodnem bazenu ob JE. Zmogljivost bazena zadostuje za shranjevanje iztrošenega goriva do 1. 2000, morda nekaj let kasneje (Poročilo...,1993). Dopolnjeno poročilo Ad hoc delovne skupine strokovnjakov o naravnih danostih lokacije JE Krško s seizmotektonskega stališča (1993) sicer glede na zbrane podatke, zaključuje, da zaradi geoloških prelomov varnost JE Krško ni ogrožena, a priporočajo dodatne geološke raziskave. Tudi z vidika varnosti in zaradi radioaktivnih odpadkov bi bilo potrebno čimprej sprejeti odločitev o predčasnem zapiranju JE Krško ali njenem obratovanju do konca življenjske dobe.

Slovenija sicer dograjuje geografski informacijski sistem, sprejema sodobnejšo zakonodajo s področja varstva okolja, najema ekološke kredite za uresničevanje slovenskega ekološkega projekta. Vendar še ni prišlo do nastanka močne skupine interesov med vlado, ozelenjenim podjetništvom in lokalno-regionalnimi iniciativami, kar bi bilo bistveno za udejanjanje ekologizacije lokalnega in regionalnega razvoja. Slovenske pokrajine, ki so onesnažene ali pa je na njihovem območju ekološko sporen objekt, bodo v bodoče zaradi zmanjšane kvalitete bivanja in izčrpanih regionalnih virov predstavljale brez temeljitih in zahtevnih ekoloških sanacij v razvoju zastajajoče regije.

Izčrpanost klasičnih spodbud za skladnejši regionalni razvoj vseh slovenskih pokrajin brez dvoma zahteva iskanje dodatnih novih razvojnih vzorcev. Zaradi kritičnega gospodarskega in socialnega položaja obstaja realna možnost, da se ob že prisotnemu iskanju bližnjice izhoda iz gospodarskih in zaposlitvenih težav izbere kratkoročno verjetno profitno donosnejša razvojna politika vlaganja le $\mathrm{v}$ določena prebivalstveno-proizvodna urbana žarišča. Naloga države je, da tudi v lastnem interesu s primernimi ukrepi uravnovesi regionalne razlike. Načela sonaravnega, uravnoteženo-trajnega razvoja prinašajo bistvene popravke v koncept skladnejšega regionalnega, pa tudi zanemarjenega prostorskega razvoja Slovenije, ki mora upoštevati regionalizem in varovanje narave ter okolja. 


\section{LITERATURA}

Bernstam M., 1991, The Wealth of Nations and the Environment, Resources, Environment and Population, Oxford, s. 333-373

Chiros D., 1988, Environmental Science, Menlo Park, s. 521

Černe A., 1993, The Transport System of Slovenia, GeoJournal 1993/3, Dordrecht, s. 339342

Dekleva J., 1992, Nacionalna strategija prostorskega razvoja Slovenije, Zbornik 12. Sedlajevega srečanja, Postojna, s. 5-7.

Dopolnjeno poročilo o naravnih danostih lokacije JE Krško s seizmotektonskega vidika, 1993, Poročevalec DZ RS 1993/23, Ljubljana, s. 43-47

Duerr H., Heintritz G., 1987, Centralismus-Regionalismus, Geographische Rundschau 1987/ 10 , Braunschweig, s. 524-526

Engelhard P., Abdallah T., 1992, Environment, Development and Poverty, The Courier 133, Brusseles, s. 31-35

Gajšek M., 1992, Primerjalna analiza evropskih regij, Zbornik 12. Sedlarjevega srečanja, Postojna, s. 165-172

Gams I., 1992, Geografske stalnice Slovenije in njeno mesto med makroregijami Evrope, Geografija v šoli 2, Ljubljana, s. 7-14

Hahne U., Maier J., 1993, Integrierte Entwicklung laendlicher Raeume-Neuere Konzepte und Erfahrungen und Uebertragung auf Schleswig-Holstein, BayreuthFlensburg,s.226

Jakoš A., 1992, Demografski potencial države Slovenije, Zbornik 12. Sedlarjevega srečanja, Postojna, s. 108-113

Jazbinšek M., Šarec A., 1991, Cestno omrežje v prostorskem planu Republike Slovenije, Zbornik, Cestarski dnevi, Bled, s. 21-24

Kakovost voda v Sloveniji, leta 1991, 1992, HMZ RS, Ljubljana, s. 176

Kennedy P., 1993, Preparing for the Twenty First Century, London, s. 428

Klemenčič V., 1992, Geopolitični položaj Slovenije in njena odprtost v Evropo, Geografija v šoli 2, Ljubljana, s. 15-24

Klemenčič V., Genorio R., 1993, The New State Slovenia and its Function with the Frame of Europe, GeoJournal 1993/3, Dordrecht, s. 335-338

Kmecl M., 1990, Slovenija brez gozda? Obup!, Ljubljana s. 73

Kurz H.,1991, Regionales Entwicklungskonzept mit dem Ziel "Hilfe durch Selbshilfe"das Beispiel des Landkreis Schwandorf, Arbeitsmaterialien zur Raumordnung und Raumplanung, Heft 102, Bayreuth, s. 187

Loetscher et al, 1987, Struktur und Regionalpolitik in der Schweiz, Geographische Rundschau 1987/10, Braunschweig, s. 563-568

Maier J., 1987, Entwicklungspolitik fuer periphere Raeume-eine Auseinandersetzung zwischen regionaler Abhaengigkeit und regionaler Selbstverwircklichung, Dela 5, Ljubljana, s. 61-70

Margulis L, Lovelock J., 1989, Gaia and Geognosy, Global Ecology, Boston s. 1-30 
Mušič V., 1992, Evropski izzivi prostorski integraciji Slovenije, Zbornik 12. Sedlarjevega srečanja, Postojna, s. 38-43

Onesnaženost zraka v Sloveniji, april 1990-marec 1991, 1991, HMZ RS, Ljubljana, s. 70 Onesnaženost zraka v Sloveniji april 1991-marec 1992, 1992, HMZ RS, Ljubljana, s. 122 Piry I., 1992, Urbani sistem Slovenije v okviru načel uravnoteženo-trajnega razvoja, Zbornik 12. Sedlarjevega srečanja, Postojna, s. 99-101

Plut D., 1991, Entropijska zanka, Radovljica, s. 151

Plut D., 1987, Slovenija- zelena dežela ali pustinja?, Ljubljana, s. 237

Plut D., Piry l., Černe A., 1984, Vloga regionalnih virov Bele krajine pri družbenem razvoju, Zbornik 13. zborovanja slovenskih geografov, Dolenjske Toplice, s. 305-317

Poročilo o jedrski nevarnosti v letu 1992, 1993, Poročevalec DZ RS 1993/23, Ljubljana, s. 48-69

Stanovnik P., Faleskini R., 1992, Promet, telekomunikacije in nekateri splošni pogoji za razvoj sodobnih tehnologij v Sloveniji, Zbornik 12. Sedlarjevega srečanja, Postojna, s. 49-53

Statistični letopis Republike Slovenije, 1993, Zavod RS za statistiko, Ljubljana, s. 530

United Nations Center for Regional Development and Work on the Environment, 1993, Nagoya, UNCRD, s. 22

Vrišer I., 1988, Centralna naselja v SR Sloveniji leta 1987, Geografski zbornik 28, Ljubljana, s. $136-189$

Vrišer I., 1990, Ekonomsko-geografska regionalizacija republike Slovenije, Geografski zbornik 90, SAZU, Ljubljana, s. 135-247

Vrišer I., 1993, Oblikovanje upravnih okrajev, Zbornik 16. zborovanja slovenskih geografov, Celje, s. 47-32

Vrišer I., 1989, Policentrizem v Sloveniji, Informativni bilten 23/5, Ljubljana, s. 11-17

Vrišer I., 1987, Regionale Entwicklung in der socialistischen Republik Slowenien, Dela 5, Ljubljana, s. 13-25

\section{THE REGIONAL DEVELOPMENT OF SLOVENIA VIEWED AS SUSTAINABLE DEVELOPMENT}

\section{Summary}

The independence and the complicated transition into a market economy is, in regard of general shifts of perceptions (global awareness, regional identity), a new challenge for the existing regional policy of Slovenia. Since the mid eighties the paradigm of the sustainable development gains support. Ecological ethics become implemented into existing development policies of most post-industrial societies. The focus is on such a persistently balanced economic activity which would take into account the carrying capacity of the limited natural resources. The "ecologisation" of regional policies would include and support regional initiatives, attentative planning and a general decentralization of statehood powers. Men- 
Regionalni razvoj Slovenije ...

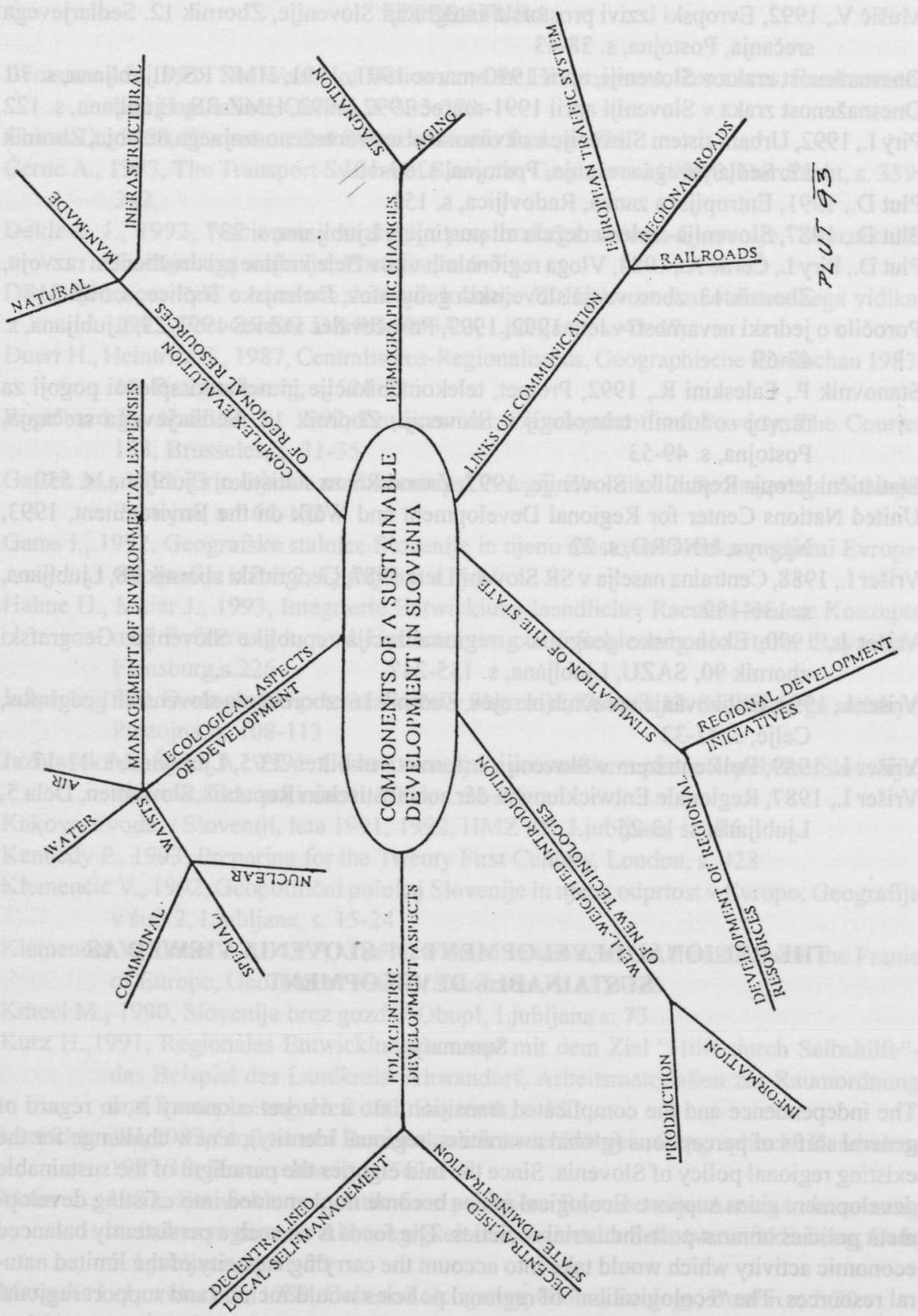


tioned principles were accepted in part already in the seventies, but never gained enough attention by people responsible for development.

If Slovenia is looking forward to implement contemporary development principles and is keen to follow activities in planning introduced by developed countries, one would do wise if, in regard to geographical constancy and geographical variables, country's regional planning would incorporate the principles of sustainability. The persistently balanced development would launch adequate changes in regional policies and would impact particularly the following geographical variables:

The production process, within which an ecosystem and socio-esthetic reevaluation (natural, human, infrastructure) would have to be made.

The demographic sources impacted by the constant decrease of the population size as a result of aging and of the interrupted migrational cycle between Slovenia and the former republics of Yugoslavia.

The traffic system, adapted to the needs of the own- state and regional interests and incorporated into European system of communicational linkages - including planning of regional highways, modernization of railroads and construction of bicycle routes.

The statehood organizational structure, introduced to support balanced regional development, with a goal to activate regional and local potentials in society and economy by incorporating autochtonous population and creating a net of regional and communal development centers. The new technics in production, information and communication, which should be wisely implemented and their ethic and ecological impact studied.

The polycentric urban system must be enforced and accomplished, and a decentralized of local self-ruled (commune - region - state) institutions including the de-concentration of state powers (district centers) should be implemented.

Policies and funds related to ecology, as they should focus particularly on the improvement of degraded landscapes and their physical elements - most often in valleys and basins where the improvement of the air quality (impacted by thermal power stations) and waters should have priority. All kinds of waste removal/deposit must be solved generally and decisions on the closing of the nuclear power station Krško reached.

The implementation of sustainibility in regional development policies is a challenge in regard to the existing, dominant planning. The recent policies promise in times of recession a false image of quick solutions and large benefits. In Slovenia has the same type of planning proved regional and ecological invalidity and non-ethical approach in forms being implemented throughout the last couple of decades. 